\title{
Sustainability and Wellbeing in Healthcare Facilities. An Investigation Inside a Historic Hospital
}

\author{
Carla Balocco $^{1 *}$, Gerardo-Lorenzo Petrone ${ }^{2}$ \\ ${ }^{1}$ Department of Architecture, DiDA, University of Florence, via Mattonaia 14, Firenze 50121, Italy \\ ${ }^{2}$ Freelance Civil Engineering of the Sani-Ingegneria, via S. Reparata 40, Firenze 50129, Italy
}

Corresponding Author Email: carla.balocco@unifi.it

https://doi.org/10.18280/ijdne.160501

Received: 5 October 2021

Accepted: 25 October 2021

\section{Keywords:}

sustainable health care facilities, health and wellbeing, environmental sustainability, ventilation effectiveness, experimental monitoring, simulation, IAQ

\begin{abstract}
Sustainability, health and well-being are strictly connected. The WHO has recently highlighted the importance of designing, management, organization and also retrofitting and refurbishment interventions for health care facilities based on climate-resilient and environmentally sustainable health criterion. In this study we propose a practical method based on the combination of physical-real and virtual information, i.e. the integration between continuous monitoring system and transient simulations, for the assessment of microclimatic and ventilation parameters, user influx/presence and behaviour, real operation (on demand) of plants and control/regulation system adjustment. The method is based on a system thinking that assures people and environment health, safety, quality of services and management, reducing energy and facility costs. Findings provided the fundamentals for training health workers and people/patients, aiming at conscious interaction for health and wellbeing protection, but also environmental sustainability and management quality. This is particularly important for healthcare environments housed in historic buildings, such as the one studied.
\end{abstract}

\section{INTRODUCTION}

Health care systems have a considerable environmental impact but they also can have positive effects on the environment. The WHO [1] has proposed a guidance on climate-resilient and environmentally sustainable health care facilities that is the results of an integrated and coordinate work and contributions of different experts within and outside the WHO. The WHO Regional Office for Europe has a clear policy mandate for action in this area. E.g., the Health 2020 , the Tallinn Charter: Health Systems for Health and Wealth and the Parma Commitment to Act on Environment and Health provide a solid basis upon which to engage in technical work, advocacy and support to Member States in policy development, adoption and implementation. Most of the researches and scientific-technical reports in this area have demonstrated that an environmentally sustainable health care system really improves, maintain or restore people health, while minimizing negative impacts on the environment and leveraging opportunities to improve it, to the benefit of health, security and well-being of current and future generations [2, 3]. Many recent works have shown that energy-environmental sustainability in health systems can be achieved with a systemic approach that recognizes the synergies between health and sustainability [4-6]. There is clear evidence that health system activities entail significant impacts and pressures on the environment. These pressures include the generation of hazardous and conventional waste, wastewater and greenhouse gas emissions, and high resources consumption (water and energy). E.g., the environmental impact of health-care waste largely depends on the method of disposal. Water pollution from health systems can originate directly from health care facilities, through patients as a result of health systems activities, through activities in the health systems supply chain, and from inadequate health-care waste disposal. As a matter of fact, pollutants in hospital wastewater include pharmaceutical products, microorganisms, heavy metals, cleaning products and other chemicals such as organic halogens or free chlorine.

Literature evidences suggest that environmental sustainability of health care systems is an effective factor/goal of safety, health and well-being for people [7-9].

They have shown that several measures oriented to sustainability, environmental quality, resilience and reversibility of interventions, can provide the potential to guarantee health and environmental benefits simultaneously: rational use of energy and renewable energy integration; design, construction and/or rehabilitation and refurbishment of buildings housing health care facilities, based on environmental quality and energy sustainability; rational and sustainable use of energy for plant systems (e.g. heating, ventilation and air conditioning, lighting systems) within health care facilities (e.g. reducing unnecessary usage, increasing energy efficiency, understanding where energy supply resilience can be improved). Others studies have highlighted that energy efficiency of building-plant systems is a crucial task, but health risk prevention deriving from environmental and pollution factors, microorganism dispersion and environmental contamination, has become a priority and requires interdisciplinary approaches with involvement of different competent subjects [10-16]. On the other hand, among stakeholders, researchers, technicians and public decision makers, awareness of the importance of indoor air quality (IAQ) for guaranteeing people's health and 
wellbeing is on the increase [17, 18].

Some recent researches concern experimental investigation on IAQ, effective ventilation, and occupant behaviour and satisfaction inside existing and newly designed buildings.

Main findings have proved that low energy consumption, IAQ, efficacy of different air flow patterns and behaviour and self-reported occupant wellbeing can be obtained by integrating building physics improvement and controlled mechanical ventilation systems [19-22]. Moreover, the current standards and provisions imposed by WHO, ASHRAE, RHEVA, AICARR and ISS, suggest that heating, ventilation and air conditioning plants (HVAC) must be working 24 hours a day and continuously 7 days a week, without air recirculation with possible night attenuation and for the non-occupation periods [23-32]. Literature on this subject has also shown that IAQ, people safety and health, environmental quality/sustainability are closely related to the air flow field and specific air flow patterns, internal pressure regimes, indoor thermo-hygrometric conditions, air filtration systems, as well as the correct maintenance and cleaning of plants and components $[10,21]$. Any intervention solution on buildingplant system, especially for historic building, should find a compromise between energy saving, energy costs necessary to ensure ventilation effectiveness and air quality, the health protection of people and cultural heritage objects.

Physical distancing and the increase in natural ventilation, both with automatic and manual techniques, are not sufficient to ensure health protection and reduction of contagion and contamination risks [12].

In this our research, a methodological approach based on the combination of physical-real and "virtual" information, i.e. measured and simulated, developed in a recent work [33] was improved and expanded. The proposed method provides a setting up continuous monitoring systems on: indoor microclimate and ventilation pattern, influx/presence and people behaviour, plants and control systems real operation conditions (on demand) and their adjustment/management.

The obtained results can be fundamental tools to draw up useful guidelines for different subjects (i.e. health workers and people/patients), training and orientation towards a conscious interaction between sustainability, health and safety protection and wellbeing, but also a better management of the environmental quality towards sustainable/resilience of healthcare facilities, as the one studied.

\section{MATERIALS AND METHODS}

\subsection{Setting}

The waiting room testing centre, of S.M. Nuova, the oldest hospital in Florence was the case study.

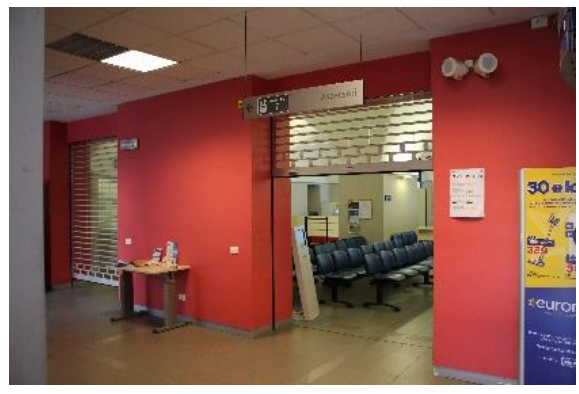

(a) Entrance

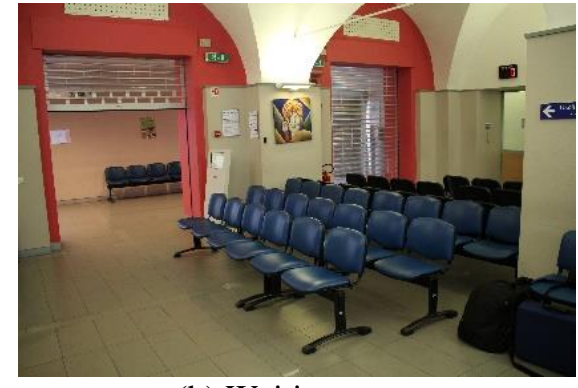

(b) Waiting room

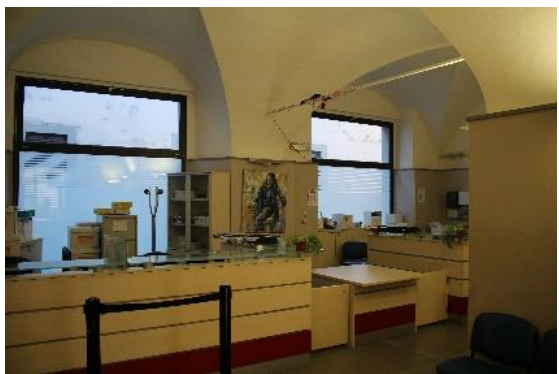

(c) Reception desks

Figure 1. Internal view of the waiting room-testing centre

From the external porch, two sliding doors lead on to the long corridor and waiting room. This latter (Figure 1) has a volume of $409 \mathrm{~m}^{3}$ with a vaulted ceiling, an average height of $3.82 \mathrm{~m}$ and an enveloping surface of very thick mixed masonry. There are two double glazed windows facing the only oriented South-West external side (Figure 1). The VAV air flow system works on an external air flow rate of $5700 \mathrm{~m}^{3} / \mathrm{h}$ with $4 \mathrm{vol} / \mathrm{h}$ air renewal. The air inlet operates through micro-nozzle diffusers located above the two sliding doors, at a supply temperature with a maximum velocity respectively of $23.2^{\circ} \mathrm{C}$ and $0.10 \mathrm{~m} / \mathrm{s}$ in winter, $26^{\circ} \mathrm{C}$ and $0.15 \mathrm{~m} / \mathrm{s}$ in summer. The total air flow rate of the two diffusers is $2240 \mathrm{~m}^{3} / \mathrm{h}$. The air conditioning system of the corridor has two circular diffusers with a helical shape on the ceiling, and two high induction and adjustable cones in anodized aluminium above the sliding doors. Each of the latter has an inlet air flow rate of $370 \mathrm{~m}^{3} / \mathrm{h}$. Air extraction takes place on the corridor ceiling through two simple order extractors of fixed anodized aluminum fins, each of them with an expulsion air flow rate of $1690 \mathrm{~m}^{3} / \mathrm{h}$. The VAV is integrated with a fourpipe radiant floor panel system that works with a delivery and return fluid temperature, respectively of $16^{\circ} \mathrm{C}$ and $20^{\circ} \mathrm{C}$ for summer, $38^{\circ} \mathrm{C}$ and $34^{\circ} \mathrm{C}$ for winter operating conditions. There are four reception desks on the window-wall side and 50 seats arranged in regular rows. The lighting system is a set of discharge lighting fixtures placed on the wall near the vault shutter.

\subsection{Experimental measurement campaign}

The environment monitoring was carried out during a short time period due to access problems connected to this type of environment and all the limitations due to the COVID-19 pandemia [33]. A measurement protocol and experimental setup were defined to obtain sequentiality, continuity and repetitiveness of the microclimatic measurements carried out in the waiting room and corridor, during a typical working week (from 12 March to 29 March 2019). Data were acquired every 5 minutes to take into account the influence of the opening/closing sliding doors and people passage. Table 1 provides the instruments list and their technical data. 
Table 1. Technical characteristic of the instruments used

\begin{tabular}{|c|c|}
\hline \multicolumn{2}{|r|}{ Flir T620 bx } \\
\hline IR resolution & $640 \times 480$ pixels \\
\hline $\begin{array}{l}\text { Thermal } \\
\text { sensitivity/NETD }\end{array}$ & $<30 \mathrm{mK} @+30^{\circ} \mathrm{C}\left(+86^{\circ} \mathrm{F}\right)$ \\
\hline Accuracy & $\begin{array}{l} \pm 2^{\circ} \mathrm{C}\left( \pm 3.6^{\circ} \mathrm{F}\right) \text { or } 2 \% \text {, whichever } \\
\text { is greater, at } 25^{\circ} \mathrm{C} \quad\left(77^{\circ} \mathrm{F}\right) \\
\text { nominal. }\end{array}$ \\
\hline \multicolumn{2}{|c|}{ Tinytag TGP-4500 } \\
\hline \multicolumn{2}{|l|}{ Temperature } \\
\hline Reading Range & $\begin{array}{l}-25^{\circ} \mathrm{C} \text { to }+85^{\circ} \mathrm{C} \quad\left(-13^{\circ} \mathrm{F} \text { to }\right. \\
\left.+185^{\circ} \mathrm{F}\right)\end{array}$ \\
\hline Sensor Type & $\begin{array}{l}\text { 10K NTC Thermistor (Internally } \\
\text { mounted) }\end{array}$ \\
\hline Accuracy & $\pm 0.5^{\circ} \mathrm{C}$ between $0^{\circ} \mathrm{C} \& 40^{\circ} \mathrm{C}$ \\
\hline \multicolumn{2}{|l|}{ Relative Humidity } \\
\hline Reading Range & $0 \%$ to $100 \% \mathrm{RH}$ \\
\hline Sensor Type & Capacitive (externally mounted) \\
\hline Accuracy & $\pm 3.0 \% \mathrm{RH}$ at $25^{\circ} \mathrm{C} / 77^{\circ} \mathrm{F}$ \\
\hline \multicolumn{2}{|c|}{$\begin{array}{l}\text { Airflow TA465 } \\
\end{array}$} \\
\hline \multicolumn{2}{|c|}{ Velocity (TA Probe) } \\
\hline Range & 0 to $9999 \mathrm{ft} / \mathrm{min}(0$ to $50 \mathrm{~m} / \mathrm{s})$ \\
\hline Accuracy & $\begin{array}{l} \pm 3 \% \text { of reading or } \pm 3 \mathrm{ft} / \mathrm{min} \\
( \pm 0.015 \mathrm{~m} / \mathrm{s}) \text {, whichever is greater }\end{array}$ \\
\hline Resolution & $1 \mathrm{ft} / \mathrm{min}(0.01 \mathrm{~m} / \mathrm{s})$ \\
\hline \multicolumn{2}{|c|}{ Temperature (TA Probe) } \\
\hline Range & 14 to $140^{\circ} \mathrm{F}\left(-10\right.$ to $\left.60^{\circ} \mathrm{C}\right)$ \\
\hline Accuracy & $\pm 0.5^{\circ} \mathrm{F}\left( \pm 0.3^{\circ} \mathrm{C}\right)$ \\
\hline Resolution & $0.1^{\circ} \mathrm{F}\left(0.1^{\circ} \mathrm{C}\right)$ \\
\hline \multicolumn{2}{|c|}{ Relative Humidity (TA Probe) } \\
\hline Range & 5 to $95 \% \mathrm{RH}$ \\
\hline Accuracy & $\pm 3 \% \mathrm{RH}$ \\
\hline Resolution & $0.1 \% \mathrm{RH}$ \\
\hline \multicolumn{2}{|c|}{ Wet Bulb Temperature (TA Probe) } \\
\hline Range & 40 to $140^{\circ} \mathrm{F}\left(5\right.$ to $\left.60^{\circ} \mathrm{C}\right)$ \\
\hline Resolution & $0.1^{\circ} \mathrm{F}\left(0.1^{\circ} \mathrm{C}\right)$ \\
\hline \multicolumn{2}{|c|}{ Dew Point (TA Probe) } \\
\hline Range & 5 to $120^{\circ} \mathrm{F}\left(-15\right.$ to $\left.49^{\circ} \mathrm{C}\right)$ \\
\hline Resolution & $0.1^{\circ} \mathrm{F}\left(0.1^{\circ} \mathrm{C}\right)$ \\
\hline
\end{tabular}

The sensors were connected to a radio master $\mathrm{R}-\log$ data logger capture system: a multifunction thermo-anemometer (10K NTC Thermistor), in the waiting room, fixed to the reinforcement chain of the cross vault; two Tinytags TGP4500 in the corridor positioned on the sign support and on the ceiling light grid (Figure 2). An infra-red FLIR thermo-camera was used to analyse the surface temperature of the walls and floor.
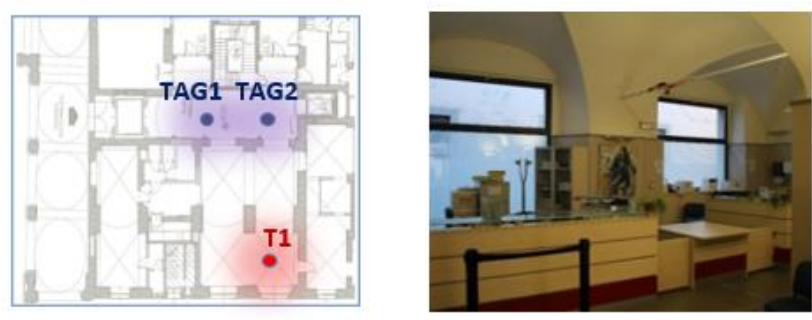

(a) Plan view: thermoanemometer (T1), tinytags (TAG1, TAG2) (b) Photo with instruments location
Figure 2. The instruments

\subsection{Computational fluid dynamics application}

The CFD transient simulations, integrated with experimental data and applied to three-dimensional models of the studied environment, were used to assess the indoor microclimate, IAQ and thermal comfort conditions. A 3D solid model, where all the different computational domains and the health care workers and patients sitting and standing were identified, was used for CFD simulations. Dynamic energy analysis of the building-plant system provided basic results in compliance with the current standards [34, 35] and was used as input data for simulations, developed for the coldest day of the monitoring campaign referred to the real external climatic data. The commercial software Designbuilder was used. From the real data on people influx and room usage time profiles, two basic conditions were identified: the first with a maximum number of 40 seated persons, and the second with a minimum of 7 with two health workers. The condition of minimum people presence was chosen as a limit and precautionary condition of quota admissions and physical distancing imposed by the pandemic context. The total thermal load due to people sitting, $63 \mathrm{~W}$ sensible heat and $39 \mathrm{~W}$ latent heat per person, clothing thermal resistance of 1 cloth [36] and the $\mathrm{CO}_{2}$ emission of $0.012 \mathrm{~m}^{3} / \mathrm{h}$ were set as boundary conditions for each patient and sanitary worker [37]. Heat loads due to the lighting system $\left(10 \mathrm{~W} / \mathrm{m}^{2}\right)$ and computers (80W/workplace) were also input [36]. Thermo-physical properties of building materials provided by the technical offices were used. Constant air temperature conditions of the surrounding rooms, provided (i.e. typical offices with $20 \pm 2{ }^{\circ} \mathrm{C}$ indoor air temperature and $50 \%$ relative humidity, for winter; [33]) were assumed as boundary conditions for the walls and ceiling. The VAV plant system, four-pipe radiant floor panel system, and the connected regulation and control system were modelled. The simulation model was calibrated and validated by means of the experimental data: standard deviation between all the measured and the corresponding calculated data was $2.8 \%$. In order to compute the basic indexes of IAQ and thermal comfort, three important sub-volumes within the room total volume were identified, once the air temperature and air velocity fields were solved. These are: the sliding door-zone (hereinafter SDZ), i.e. the air volume that extends $0.61 \mathrm{~m}$ from the doors and the wall for the entire height of the room and adjacent to the first rows of seats, including the two micronozzle diffusers; the patients-sitting-zone (hereinafter PSZ), i.e. the air volume that includes all the rows of chairs and therefore the area occupied by people/patients for the entire height of the room. In particular, referring to [38], PSZ was defined as encompassing all space from the floor level to $1.83 \mathrm{~m}$ above the floor by excluding the space from the wall to $0.61 \mathrm{~m}$ away from any wall. The sanitary workers-zone (hereinafter SWZ), i.e. the air volume that includes all the workstations of healthcare workers up to the opposite glazed wall for the entire height of the room, is the third sub-volume of the room. For each of these sub-volumes/zones the following fundamental indexes were calculated. The local mean air age (LMA) that is one of the most important parameters to evaluate the ventilation efficiency and/or contaminants removal and to quantify the average lifetime of air at a closed space for a steady airflow achieved. LMA expresses the average time for air to travel from a supply inlet area to any location in a forced ventilated room, therefore, lower values are more favourable and at the inlet opening it was assumed to be zero (100\% fresh). Comparison of LMA 
values with the theoretical residence time of air inside the room (i.e. the ratio between the total volume of the room and the mass flow rate of incoming ventilating air), provided the fundamentals for the Air Exchange Efficiency (AEE) index computation. In particular, applying a zonal method and referring to the LMA results obtained for the considered zone, the AEE was calculated by the formula:

$$
A E E=\frac{\left(1 /{ }_{A C H}\right)_{\text {real }}}{\text { LMA }_{\text {calculated }}}
$$

The Air Diffusion Performance Index (ADPI), that allows the quantification of diffusers performance with respect to the air velocity and temperature spatial uniformity, and their contribution to thermal comfort, was calculated. ADPI is defined as the percentage of occupied zone within which the acceptable velocity and temperature values, determined as function of the local Effective Draft Temperature (EDT), are satisfied [39]. The existing VAV plant inside the waiting-room is based on a typical better-mixing ventilation/air distribution system with high side-wall located nozzles. Therefore, it was possible to apply the method proposed by Liu and Novoselac [40] for the heating mode assessment. The EDT in heating mode was defined by comparing the region of EDT in the ADPI method to the region of $80 \%$ thermal comfort in the Predicted Mean Vote (i.e. PMV, the Fanger index for thermal comfort, [36] then deriving a heating mode EDT and applying the ADPI method in terms of the derived heating mode EDT. The ADPI is implicitly linked to thermal comfort and was developed mainly for mixing ventilation/air distribution aiming to achieve a uniform air condition: higher ADPI value corresponds to a higher mixing level in the space.

The heating mode EDT was calculated using the formula suggested by Liu and Novoselac [40] applied to each point of cell that identifies the specific air sub-volume:

$$
E D T=\left(T_{p}-T_{a}\right)-9.1 *\left(v_{p}-0.15\right)
$$

with $\mathrm{T}_{\mathrm{p}}$ local air dry bulb temperature at each point of the cell defining the sub-volume/zone considered $\left({ }^{\circ} \mathrm{C}\right), \mathrm{T}_{\mathrm{a}}$ mean air dry bulb temperature in the environment/total-volume (i.e. the HVAC system set-point value $\left({ }^{\circ} \mathrm{C}\right)$ ) and $\mathrm{v}_{\mathrm{p}}$ mean air velocity at each point of the cell describing the considered subvolume/zone, i.e. local airstream centerline velocity $(\mathrm{m} / \mathrm{s})$. The optimal EDT value for heating mode, which guarantees comfort conditions for people with poor metabolic activity and sessions, is in the range $-2.2^{\circ} \mathrm{C}$ and $2^{\circ} \mathrm{C}$, assuming the criterion of the air velocity value less than or equal to $0.35 \mathrm{~m} / \mathrm{s}$ corresponding to the occupants comfort condition due to air velocity higher than $0.2 \mathrm{~m} / \mathrm{s}$ for warm air, as reported in [38]. Because the isothermal throw length of each diffuser for the terminal velocity of $0.25 \mathrm{~m} / \mathrm{s}$ was provided by diffuser manufacturer catalogue, in accordance with the airflow rate, using the EDT (Eq. (2)) for heating mode, the ADPI value was calculated by means of the calculated air velocity and temperature data obtained from CFD simulation, as suggested in the studies [40-42]. The PMV and PPD indexes were calculated by means of the software CFD dedicated application in accordance with [36].

\section{RESULTS AND DISCUSSION}

\subsection{Indoor microclimate monitoring}

The waiting room microclimatic parameters obtained during the monitoring campaign are provided in Table 2: it can be noted the reability and accuracy of measured data. The mean air temperature and velocity values in the corridors and in the waiting, room agree with those suggested [23-35]. However, the relative humidity values are generally lower. Results of the surface temperature analysis carried out by the infrared FLIR camera are shown in Figure 3.

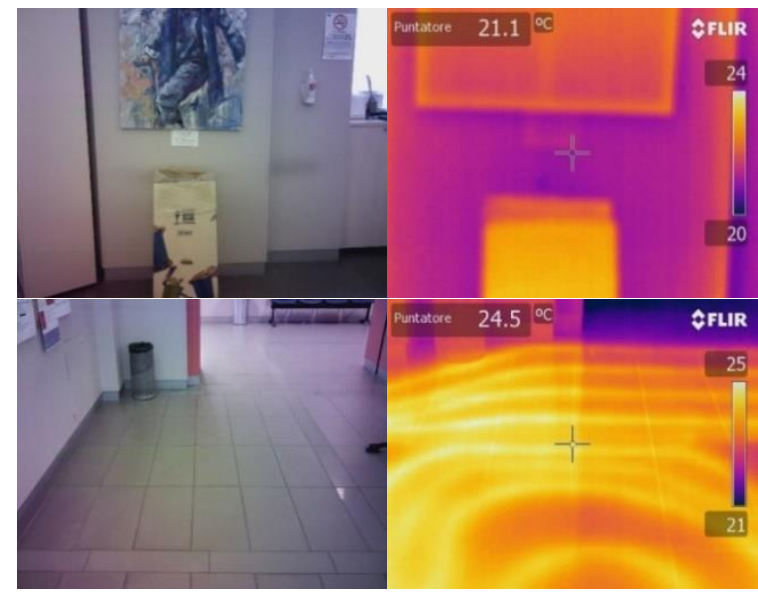

Figure 3. Infrared thermo-camera FLIR investigation: at the top, real photo South-West wall (left) and its FLIR image (right); at the bottom, real photo of the floor towards the sliding doors (left) and its FLIR image (right)

The trends of the mean air temperature and relative humidity indoor and outdoor, for the coldest day of the monitoring campaign are provided in Figure 4. It can be noted, especially during the central hours of the day, how the internal air temperature of the waiting room is affected by the mutual influence between people influx, door opening and closing phases, and higher values of the external air temperature. In the corridor this value is always lower, due to the continuous people passage and greater influence of sliding doors opening and closing. The effect of thermal-buffer and humiditydamping of the corridor on the thermo-hygrometric conditions of the waiting room, compared to the external climatic conditions, is evident if the trend of the relative humidity values is taken into account (Figure 4).

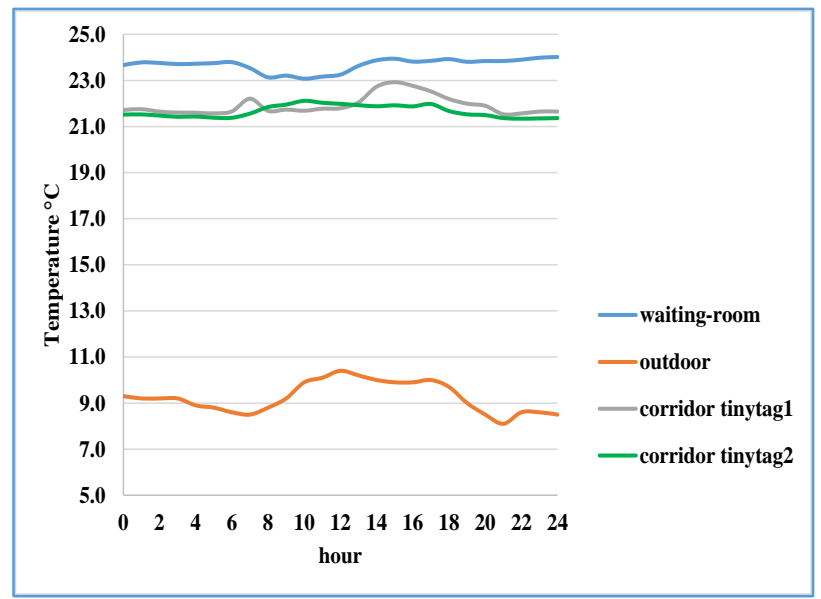

(a) Air temperature 


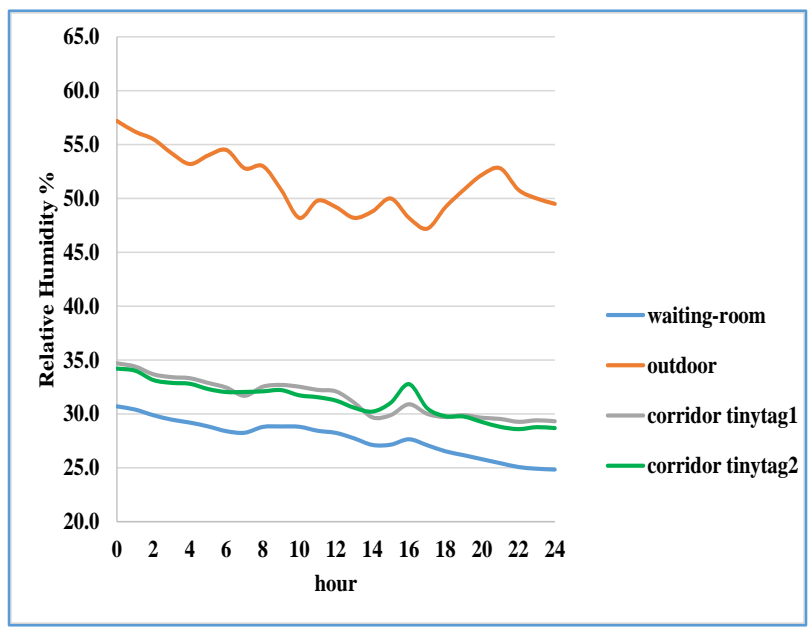

(b) Relative humidity

Figure 4. Hourly data measured in the waiting room and corridor in relation to the real data for the coldest day of the experimental campaign

Table 2 provides the results of measured microclimatic parameters: good data reability and accuracy can be noted. The mean air temperature in the corridors, but especially in the waiting room, as well as the air velocity value, agree with those suggested [23-36], the relative humidity values are generally lower.

Table 2. Basic results of the experimental measurements

\begin{tabular}{|c|c|c|c|c|c|}
\hline & $\begin{array}{c}\text { Air } \\
\text { velocity } \\
(\mathrm{m} / \mathrm{s})\end{array}$ & $\begin{array}{l}\text { Air } \\
\text { temp. } \\
\left({ }^{\circ} \mathrm{C}\right)\end{array}$ & $\begin{array}{c}\text { Relative } \\
\text { humidity } \\
(\%)\end{array}$ & $\begin{array}{l}\text { Wet- } \\
\text { bulb } \\
\text { air } \\
\text { temp. } \\
\left({ }^{\circ} \mathrm{C}\right)\end{array}$ & $\begin{array}{l}\text { Specific } \\
\text { humidity } \\
\left(g_{v} / g_{a . s}\right)\end{array}$ \\
\hline \multicolumn{6}{|c|}{ waiting room-thermo anemometer } \\
\hline Mean & 0057 & 23.67 & 27.74 & 13.06 & 5.128 \\
\hline $\max$ & 0.110 & 24.40 & 30.80 & 13.60 & 5.686 \\
\hline Min & 0.020 & 23.00 & 24.70 & 12.70 & 4.669 \\
\hline Median & 0.060 & 23.80 & 28.20 & 12.95 & 5.113 \\
\hline $\begin{array}{l}\text { standard } \\
\text { deviation }\end{array}$ & 0.014 & 0.316 & 1.598 & 0.266 & 0.265 \\
\hline \multicolumn{6}{|c|}{ corridor tinytag 1} \\
\hline Mean & - & 21.93 & 31.45 & - & 5.213 \\
\hline $\max$ & - & 23.15 & 34.88 & - & 5.848 \\
\hline Min & - & 21.49 & 28.90 & - & 4.683 \\
\hline Median & - & 21.74 & 31.98 & - & 5.279 \\
\hline $\begin{array}{l}\text { standard } \\
\text { deviation }\end{array}$ & - & 0.430 & 1.706 & - & 0.252 \\
\hline \multicolumn{6}{|c|}{ corridor tinytag 2} \\
\hline mean & - & 21.66 & 31.23 & - & 5.095 \\
\hline $\max$ & - & 22.18 & 36.70 & - & 6.128 \\
\hline $\min$ & - & 21.32 & 28.34 & - & 4.531 \\
\hline median & - & 21.54 & 31.33 & - & 5.161 \\
\hline $\begin{array}{l}\text { standard } \\
\text { deviation }\end{array}$ & - & 0.267 & 1.639 & - & 0.290 \\
\hline
\end{tabular}

\subsection{CFD transient simulations}

In this section, transient CFD simulation results obtained for the characteristic day and for the two conditions of maximum and minimum people presence are analysed and discussed. Air velocity field on different section planes for the condition of maximum and minimum people presence are respectively shown in Figure 5: in the first condition, a visible effect of short-circuiting and partial air stagnation in the occupied zone can be noted. This effect is absent for minimum people presence condition: air velocity distribution is much more uniform throughout the total volume of the environment with relatively higher velocity values near the ceiling, where the Coanda effect, the shape of the jet and the effect of the launch length from the delivery diffusers, combined with the different temperature distributions, are evident (Figures 5, 6).

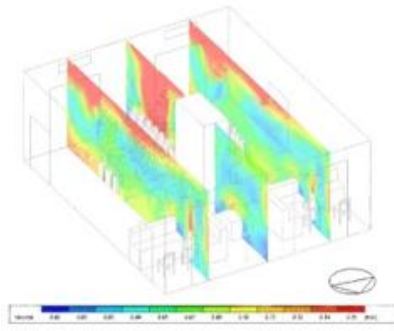

(a) max people presence condition

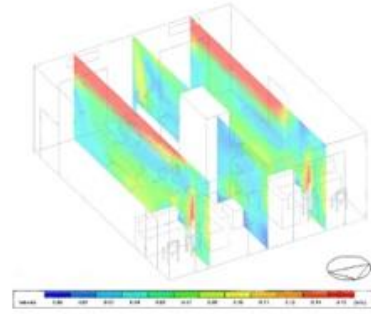

(c) min people presence condition

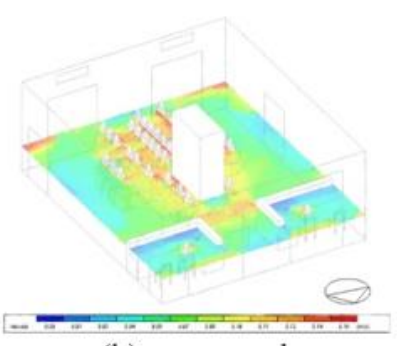

(b) max people presence condition

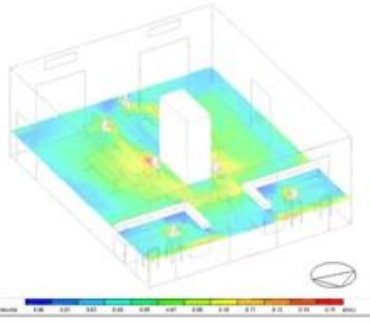

(d) min people presence condition
Figure 5. CFD simulation results for air velocity field at two different section planes

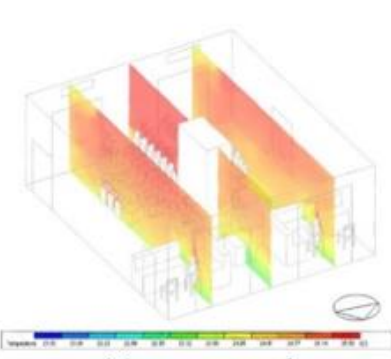

(a) max people presence condition

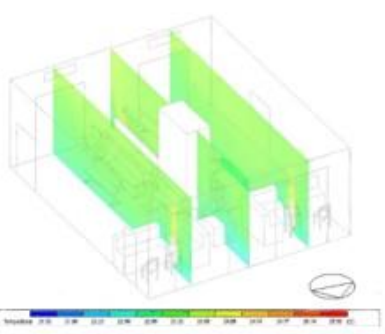

(c) min people presence condition

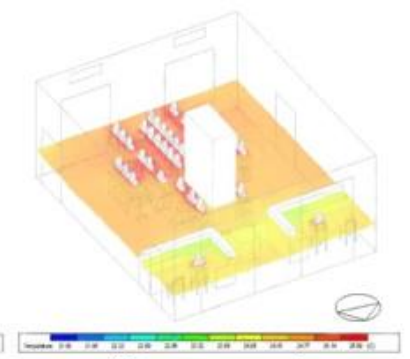

(b) max people presence condition

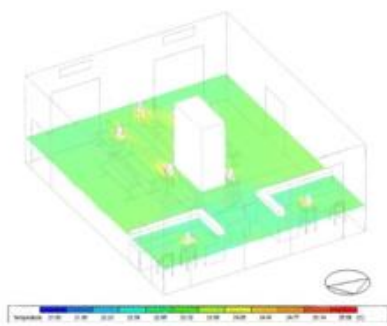

(d) min people presence condition
Figure 6. CFD simulation results for air temperature distribution at two different section planes

For the max and min people presence condition, the air flow pattern in the room total volume is strongly conditioned by stagnant flow above the occupied zone, due to the combined effect of hot air buoyancy towards the ceiling and thermal 
plume above people sitting (Figures 5, 6). Considering the air temperature distribution, it can be noted that for the max people presence condition, the values are on average higher, both in the total environment, and in the sitting zone, compared to those obtained for the min people presence condition (Figure 6). As expected, the zone near the double glazed wall, facing South-West, has lower air temperature values for both conditions. For people thermal comfort evaluation, strictly connected to the air quality due to ventilation effectiveness, the EDT and ADPI were calculated for all the three sub-volumes, SDZ, PSZ, SWZ, at max and min people presence conditions. Results are reported in Table 3. A threshold limit value of ADPI $>80 \%$ was assumed for the ADPI computation referred to SDZ, PSZ, SWZ. This assumption corresponds to the condition with the occupied space falling into the equation boundaries and having a high air mixing level and high uniformity of the air velocity distribution.

Table 3. Results of the experimental measurements

\begin{tabular}{cccccc}
\hline $\begin{array}{c}\text { Sub- } \\
\text { volume/ } \\
\text { zone }\end{array}$ & Condition & $\begin{array}{c}\text { AEE } \\
(-)\end{array}$ & $\begin{array}{c}\text { LMA } \\
\text { A }(\mathbf{s})\end{array}$ & $\begin{array}{c}\text { EDT } \\
\left({ }^{\circ} \mathbf{C}\right)\end{array}$ & $\begin{array}{c}\text { ADPI }> \\
\mathbf{8 0 \%}\end{array}$ \\
\hline SDZ & $\begin{array}{c}\text { max people } \\
\text { presence }\end{array}$ & 0.78 & 8.01 & 0.74 & ok \\
PSZ & $\begin{array}{c}\text { max people } \\
\text { presence }\end{array}$ & 0.33 & 10.91 & 0.75 & ok \\
SWZ & $\begin{array}{c}\text { max people } \\
\text { presence }\end{array}$ & 0.27 & 12.35 & 0.36 & ok \\
SDZ & $\begin{array}{c}\text { min people } \\
\text { presence } \\
\text { min people } \\
\text { presence }\end{array}$ & 0.72 & 5.81 & 0.54 & ok \\
PSZ & $\begin{array}{c}\text { min people } \\
\text { presence }\end{array}$ & 0.87 & 10.73 & 0.57 & ok \\
\hline SWZ & & & & 1.16 & ok \\
\hline
\end{tabular}

However, thermal comfort also depends on some important parameters like as air relative humidity, mean radiant temperature, metabolic rate and clothing insulation of people. Then, the ADPI can be used for the assessment of effective draft temperature field in the occupied zone of the environment studied, that means the assessment of the air flow pattern performance and uniformity of the air velocity distribution. For the max people presence condition, it can be noted a significant reduction of the local AEE and the simultaneous higher growth of the LMAA from SDZ to SWZ (Table 3). This trend is also present for the minimum people presence condition, but with relatively higher AEE with optimal values in the PSZ and SWZ, proportional to the reduction of the local LMAA value for all the three subvolumes/zones (Table 3). Results comparison from Table 3, show that there are no very important differences between the three different zones in terms of AEE, LMAA and EDT. So much so that even the ADPI index is always satisfied for all the three zones: this is due to the good mixing condition obtained with a highly homogeneous air inlet diffuser system from the top/ceiling and with the plant integration between the $\mathrm{VAV}$ with $4 \mathrm{vol} / \mathrm{h}$ air renewal, and the floor radiant panel system. These results are consistent with recent literature researches [43-47].

These results are also confirmed by the VMP, PPD and operative temperature maps (Figure 7a-f). Although the relative humidity is generally low (a condition imposed on the regulation and control system, as indicated by the technical office), people well-being conditions are generally guaranteed, as can be deduced comparing PMV and PPD distribution (Figure $7 \mathrm{a}, \mathrm{c}$ ) with the operative temperature distribution (Figure 7b, d). However, the SWZ, i.e. the zone around the large glazed surface, shows a local discomfort, as expected from the local PVM and building's thermo-physical behaviour assessment: this is due to the local air thermal stratification, more properly caused by the mean radiant temperature asymmetry.

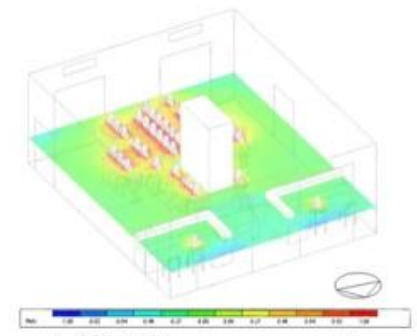

(a) PMV at max people presence condition

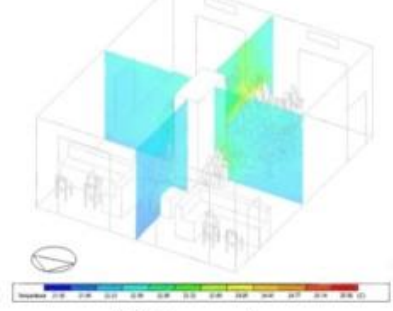

(b) Operative temperature at max people presence condition

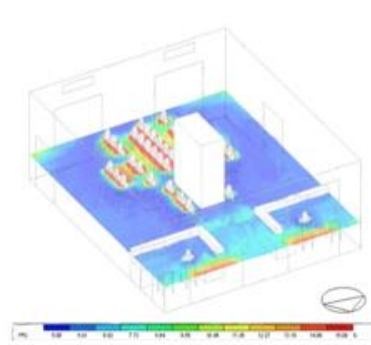

(c) PPD at max people presence condition

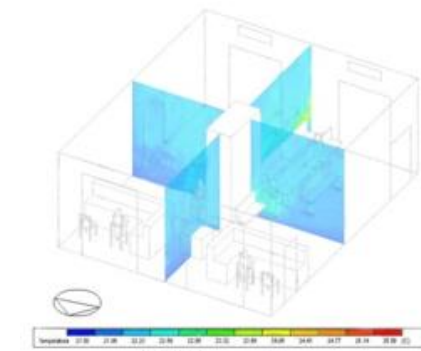

(e) Operative

temperature at $\mathrm{min}$ people presence condition (d) PMV at min people presence condition
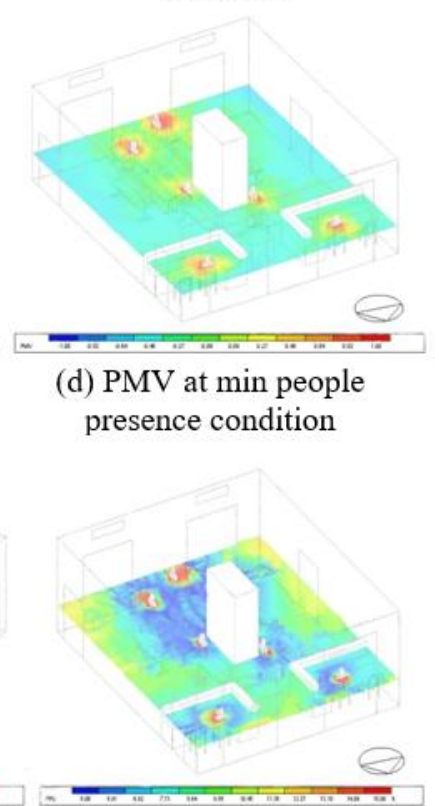

(f) PPD at min people presence condition
Figure 7. CFD simulation results on different section planes

Within the air flow scheme modelling of the total volume of the room, the PMV and PPD distribution at the two investigated people presence conditions, may produce acceptable values both for low air temperature with low air velocity and high air temperature with high air velocity. But this cannot happen for the ADPI also computed for the room total volume. The reason why the ADPI value can be high, when PPD is high, is due to the fact that for the existing air flow ventilation scheme, the hot air stagnates on the ceiling of the room and the occupied area below, still has a relatively uniform air velocity and temperature distribution. From result comparisons, it can be seen how the air motion field, temperature distribution and the trend of the LMAA values, both for precautionary conditions of max people presence, and for the min people presence condition with physical distancing and limited entrances, the HVAC plant with demand- 
controlled ventilation combined with floor radiant panel system, guarantees air quality, good ventilation and comfortable conditions for occupants. Analysing the variability of the aforementioned and assessed parameters and indexes, it can be deduced that the environmental quality, health, wellbeing and safety, cannot be guaranteed by air permeability of the building envelope and natural ventilation due to manual window/door airing, as also deeply demonstrated in the study [12]. In particular, as expected, ventilation effectiveness and air washing effect are present in all the three SDZ, PSZ and SWZ, both at max and min people presence conditions, but with better results for the min people presence condition.

\section{CONCLUSIONS}

The energy-environmental sustainability of health care facilities implies the realization and management of buildingplant system projects that aim at the IAQ and ventilation effectiveness, but at the same time at hygiene, safety and health of the occupants.

This fact implies that they can only be reversible, adaptive and resilient. Moreover, health, safety and wellness of people can be achieved with HVAC plant system designs finalised to IAQ, solutions based on demand ventilation regulation and control, airflow scheme effectiveness and correct air change rates $[42,48]$.

The methodological approach, that was developed in this present research, based on a systemic view for design and organisation processes of building-plant system, can be a useful tool to define climate resilience guidelines for the health care facilities, especially for those housed inside historic buildings. The proposed method should be understood as a living document for continuous improvement, ongoing collaboration, and focused contribution to health care facilities management, organization and planning.

The body of the living/resilient knowledge/information of the method, is the integration between continuous monitoring system and transient simulations, for the assessment of microclimatic and ventilation parameters, user influx/presence and behaviour, real operation (on demand) of plants and control/regulation system adjustment.

The proposed perspective and systemic vision approach can be used as a crucial support for a Living Facility Report to capture current best practices and enable continuous improvements through an iterative and collaborative process for sustainable, resilient and healthy/comfortable health care systems. It can also be easily correlated and interfaced with DIGITAL TWIN simulation and modelling systems. This is particularly mandatory for healthcare environments such as the one studied and also provides the key elements to stimulate effective participatory/training processes, supporting BIM techniques for facility management and maintenance, enhancing the ability to plan and implement intervention scenarios on critical elements, analysing and evaluating technologies/performance, IAQ/wellbeing, health/hygiene, energy and maintenance costs and management.

\section{ACKNOWLEDGMENT}

The authors thank: Eng. Luca Meucci, executive manager of the USL Toscana Centro; Antonio Croce expert technical office of S.M. Nuova Hospital; Dr. Luca Fibbi of the Centre LAMMA CNR IBIMET of Florence, for providing Florence climate data.

\section{REFERENCES}

[1] WHO guidance for climate-resilient and environmentally sustainable health care facilities. Geneva: World Health Organization. (2020). Licence: CC BY-NC-SA 3.0 IGO.

[2] WHO. (2018). Health-care waste. URL: www.who.int/news-room/factsheets/detail/health-carewaste, accessed on 2 August 2018.

[3] WHO and Healthcare Without Harm. (2009). Healthy Hospitals, Healthy Planet, Healthy People: Addressing climate change in healthcare settings, www.who.int/globalchange/publications/healthcare_sett ings/en, accessed 2 May 2018.

[4] CABE. (2009). Future health Sustainable places for health and well-being. Ed. Commission for Architecture and the Built Environment

[5] WHO, Health Care Without Harm. (2009). Ministry of Health. 2019. Sustainability and the Health Sector: A guide to getting started. Wellington.

[6] Sustainable Health Review. (2019). Final Report to the Western Australian Government. Department of Health, Western Australia.

[7] Gola, M., Settimo G., Capolongo S. (2020). Reaching sustainability in healthcare: strategies for a healthy indoor air quality in healing environments. In: Bevilacqua C., Calabrò F., Della Spina L. (eds) New Metropolitan Perspectives. NMP 2020. Smart Innovation, Systems and Technologies, vol 177. Springer, Cham. https://doi.org/10.1007/978-3-030-52869-0_14

[8] Gola, M., Mele, A., Tolino, B., Capolongo, S. (2017). Applications of IAQ monitoring in international healthcare systems. In: Capolongo, S., Settimo, G., Gola, M. (eds.) Indoor Air Quality in Healthcare Facilities. SPH: 27-39. Springer, Cham (2017). https://doi.org/10.1007/978-3-319-49160-8_3

[9] Balabel, A., Alwetaishi, M. (2021). Toward sustainable healthcare facilities: An initiative for development of "Mostadam-HCF" rating system in Saudi Arabia. Sustainability, $13: \quad 6742$. https://doi.org/10.3390/su13126742

[10] Becchetti, L., Beccari, G., Conzo, G., Conzo, P., De Santis, D., Salustri, F. (2021). Air quality and COVID19 adverse outcomes: Divergent views and experimental findings. Environmental Research, 193: 110556. https://doi.org/10.1016/j.envres.2020.110556

[11] Zhang, Y., He, M., Wu, S., Zhu, Y., Wang, S., Shima, M., Ma, L. (2015). Short-term effects of fine particulate matter and temperature on lung function among healthy college students in Wuhan, China. Int. J. Environ. Res. Publ. Health, 12(7): 7777-779. https://doi.org/10.3390/ijerph120707777

[12] Chanjuan, S., Zhiqiang, Z.J. (2020). The efficacy of social distance and ventilation effectiveness in preventing COVID-19 transmission. Sustainable Cities and $\quad$ Society, 102390. https://doi.org/10.1016/j.scs.2020.102390

[13] Dai, H., Zaho, B. (2020). Association of the infection probability of COVID-19 with ventilation rates in confined spaces. Building Simulation, 13: 1321-1327. 
https://doi.org/10.1007/s12273-020-0703-5

[14] Buonanno, G., Stabile, L., Morawska, L. (2020). Estimation of airborne viral emission: Quanta emission rate of SARS-CoV-2 for infection risk assessment. Environment International, 141: 105794. https://doi.org/10.1016/j.envint.2020.105794

[15] Chartier, Y., Atkinson, J., Pessoa-Silva, C. (2009). Natural ventilation for infection control in health-care settings. World Health Organization. ISBN-13: 978-924-154785-7.

[16] He, Q., Niu, J., Gao, N., Zhu, T., Wu, J. (2010). CFD study of exhaled droplet transmission between occupants under different ventilation strategies in a typical office room. Building and Environment, 46(2): 397-408. https://doi.org/10.1016/j.buildenv.2010.08.003

[17] Cheng, S.Y., Wang, C.J., Shen, A.C.T., Chang. S.C. (2020). How to safely reopen colleges and universities during COVID-19: Experiences from Taiwan. Annals of Int. Medicine. https://doi.org/10.7326/M20-2927

[18] Pinzone, M., Lettieri, E., Masella, C. (2012). Sustainability in healthcare: Combining organizational and architectural levers. International Journal of Engineering Business Management, 4(38). https://doi.org/10.5772/54841

[19] Lipinskia, T., Ahmad, D., Sereyb, N., Jouhara, H. (2020). Review of ventilation strategies to reduce the risk of disease transmission in high occupancy buildings. Int. J. of Thermofluids, 7-8: 100045 https://doi.org/10.1016/j.ijft.2020.100045

[20] Churazova, A. (2020). Displacement Ventilation vs. Mixing Ventilation. SimScale. www.simscale.com/blog/2017/12/displacementventilation-cfd.

[21] Guo, M., Xu, P., Xiao, T., He, R., Dai, M., Miller, S.L. (2021). Review and comparison of HVAC operation guidelines in different countries during the COVID-19 pandemic. Building and Environment, 187: 107368. https://doi.org/10.1016/j.buildenv.2020.107368

[22] Zhang, Y., Han, O., Li, A., Hou, L., Olofsson, T., Zhang, L., Lei, W. (2021). Adaptive wall-based attachment ventilation: A comparative study on its effectiveness in airborne infection isolation rooms with negative pressure. Engineering. https://doi.org/10.1016/j.eng.2020.10.020

[23] Italian Higher Institute of Health. Interim Indications for the Prevention and Management of Indoor Environments in Relation to the Transmission of the SARS-CoV-2 Virus Infection. Version of 23 March 2020; 10 p. ISS COVID-19 Reports No. 5/2020. ISS Environment and Indoor Air Quality 2020 Working Group ii: 2020. https://www.iss.it/coronavirus.

[24] AICARR. (2020-I). The Plants and the Spread of SARSCOV2-19 in the Workplace. AICARR (2020). https://www.aicarr.org/Pages/Normative/FOCUS_COV ID-19_IT.aspx.

[25] AICARR (Italian Association of Air Conditioning, Heating and Refrigeration). (2020-II). AICARR Position on the Operation of Air Conditioning Systems During the SARS-COV2-19 Emergency. https://www.aicarr.org/Pages/Normative/FOCUS_COV ID-19_IT.aspx.

[26] AICARR (Italian Association of Air Conditioning, Heating and Refrigeration). (2020). Protocol for the Reduction of the Risk from the Spread of SARS-COV219 in the Management and Maintenance Operations of
Existing Air Conditioning and Ventilation Systems, https://www.aicarr.org/Pages/Normative/FOCUS_COV ID-19_IT.aspx.

[27] USEPA, U.S. Environmental Protection Agency. (2020). Report of the Environment: Indoor Air Quality. Available online: https://www.epa.gov/reportenvironment/indoor-air-quality, accessed on 19 April 2020.

[28] REHVA How to Operate and Use Building Services in order to Prevent the Spread of the Coronavirus Disease (COVID-19) virus (SARS-CoV-2) in WorkplacesREHVA COVID-19 Guidance Document, 3 April 2020 (This Document Updates 17 March Version, Updates will Follow as Necessary).

[29] EPA, Environmental Protection Agency (EPA), Guidance 2020: Indoor Air and Coronavirus (COVID19). https://www.epa.gov/coronavirus/indoor-air-andcoronavirus-covid-19.

[30] ASHRAE April 2020, Issues and Statements on Relationship Between COVID-19 and HVAC in Buildings. Available online: https://www.ashrae.org/about/news/2020/ashrae-issuesstatements-on-relationship-between-covid-19-and-hvacin-buildings.

[31] WHO 2020-I. Getting your Workplace Ready for COVID-19. Geneva, Switzerland 2020

[32] WHO 2020-II. Water, Sanitation, Hygiene and Waste Management for COVID-19. Geneva, Switzerland 2020.

[33] Balocco, C., Petrone, G.L. (2021). Microclimatic and ventilation conditions in existing healthcare facilities. A study in the waiting room-testing centre of a Florentine historic hospital. Tecnica Italiana-Italian Journal of Engineering Science, 65(2-4): 317-323. https://doi.org/10.18280/ti-ijes.652-427

[34] EN 16798-3:2017 Energy Performance of BuildingsVentilation for Buildings-Part 3: For Non-Residential Buildings-Performance Requirements for Ventilation and Room-Conditioning Systems Modules:M5-1,M5-4.

[35] EN 15251:2008. Indoor Environmental Input Parameters for Design and Assessment of Energy Performance of Buildings Addressing Indoor Air Quality, Thermal Environment, Lighting and Acoustics. http://store.uni.com/catalogo/uni-en-15251-2008.

[36] UNI EN ISO 7730:2006. Ergonomics of Thermal Environments-Analytical Determination and Interpretation of Thermal well-being by Calculating the PMV and PPD Indices and Local Thermal Well-Being Criteria. http://store.uni.com/catalogo/index.php/uni-eniso-7730-2006.

[37] Persily, A., De Jonge, L. (2017). Carbon dioxide generation rates for building occupants. Indoor Air, 27(5): 868-879. https://doi.org/10.1111/ina.12383

[38] ANSI/ASHRAE Standard 55-2010. Thermal Environmental Conditions for Human Occupancy.

[39] ANSI/ASHRAE Standard 113-2009 Method of Testing for Room Air Diffusion.

[40] Liu, S.C., Novoselac, A. (2015). Air Diffusion Performance Index (ADPI) of diffusers for heating mode. Building and Environment, 87: 215-223. https://doi.org/10.1016/j.buildenv.2015.01.021

[41] Memarzadeh, F., Manning, A. (2000). Thermal Comfort, Uniformity, and Ventilation Effectiveness in Patient Rooms: Performance Assessment Using Ventilation Indices. Symposium, ASHRAE Transactions, 
Conference Proceeding by ASHRAE, 2000 vol. 106.

[42] Sundell, J., Levin, H., Nazaroff, W.W., Cain, W.S., Fisk, W.J., Grimsrud, D.T., Gyntelberg, F., Li, Y., Persily, A.K., Pickering, A.C. (2011). Ventilation rates and health: Multidisciplinary review of the scientific literature. Indoor Air, 21: 191-204. https://doi.org/10.1111/j.1600-0668.2010.00703.x

[43] Awbi, H.B. (2017). Ventilation for good indoor air quality and energy efficiency. Energy Procedia, 112: 277-286. https://doi.org/10.1016/j.egypro.2017.03.1098

[44] Saheb, H.A., Mahdi, A.A., Al-amir, Q.R. (2021). A comparative study of performance between two combined ventilation systems and their effect on indoor air quality and thermal comfort inside office rooms. IOP Conf. Series: Materials Science and Engineering, 1095. https://doi.org/10.1088/1757-899X/1095/1/012001

[45] Valdiserri, P., Cesari, S., Coccagna, M., Romio, P., Mazzacane, S. (2020). Experimental data and simulations of performance and thermal comfort in a patient room equipped with radiant ceiling panels. Buildings, 10

https://doi.org/10.3390/buildings10120235

[46] Lin, Z. (2011). Effective draft temperature for evaluating the performance of stratum ventilation. Building and Environment, 46 : $1843-1850$. https://doi.org/10.1016/j.buildenv.2011.03.005

[47] Cao, G., Awbi, H., Yao, R., Fan, Y., Sirén, K., Kosonen, R., Zhang, J. (2014). A review of the performance of different ventilation and airflow distribution systems in buildings. Building and Environment, 73: 171-186. https://doi.org/10.1016/j.buildenv.2013.12.009

[48] Yang, S., Pernot, J.G., Jörin, C.H., Niculita-Hirzel, H., Perret, V., Licina, D. (2020). Energy, indoor air quality, occupant behavior, self-reported symptoms and satisfaction in energy-efficient dwellings in Switzerland. Build. $\quad$ Environ., 171 : 106618. https://doi.org/10.1016/j.buildenv.2019.106618 